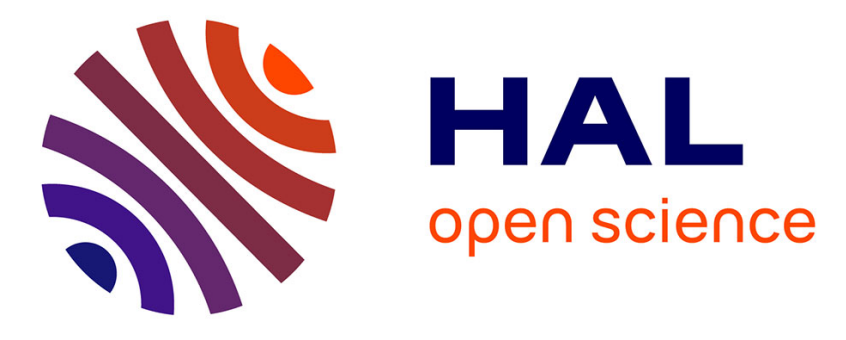

\title{
Major volatiles evolved from eolian materials in Gale crater
}

Jennifer Stern, Brad Sutter, P. Douglas Archer, Jennifer L. Eigenbrode, Amy

Mcadam, Heather B. Franz, Christine Knudson, Douglas W. Ming, Gregory

Wong, Caroline Freissinet, et al.

\section{To cite this version:}

Jennifer Stern, Brad Sutter, P. Douglas Archer, Jennifer L. Eigenbrode, Amy Mcadam, et al.. Major volatiles evolved from eolian materials in Gale crater. Geophysical Research Letters, 2018, 45 (19), pp.10,240-10,248. 10.1029/2018GL079059 . insu-01876721

\section{HAL Id: insu-01876721 \\ https://hal-insu.archives-ouvertes.fr/insu-01876721}

Submitted on 6 Nov 2020

HAL is a multi-disciplinary open access archive for the deposit and dissemination of scientific research documents, whether they are published or not. The documents may come from teaching and research institutions in France or abroad, or from public or private research centers.
L'archive ouverte pluridisciplinaire HAL, est destinée au dépôt et à la diffusion de documents scientifiques de niveau recherche, publiés ou non, émanant des établissements d'enseignement et de recherche français ou étrangers, des laboratoires publics ou privés. 


\section{Geophysical Research Letters}

\section{RESEARCH LETTER}

10.1029/2018GL079059

\section{Special Section:}

Curiosity at the Bagnold Dunes, Gale crater: Advances in

Martian eolian processes

\section{Key Points:}

- Eolian materials generally possessed more $\mathrm{O}_{2}, \mathrm{CO}_{2}$, and $\mathrm{NO}$ than sedimentary materials in Gale crater

- The presence of $\mathrm{CO}_{2}$ that evolved at temperatures greater than $\mathbf{4 5 0}$ degrees Celsius is consistent with the presence of carbonate in the eolian materials

- Differences in evolved gases between dust-bearing and dust-free eolian materials suggest that dust on Mars is enriched in volatiles

Supporting Information:

- Supporting Information S1

Correspondence to:

J. C. Stern,

jennifer.c.stern@nasa.gov

Citation:

Stern, J. C., Sutter, B., Archer, P. D., Eigenbrode, J. L., McAdam, A. C., Franz, H. B., et al. (2018). Major volatiles evolved from eolian materials in Gale crater. Geophysical Research Letters, 45, 10,240-10,248. https://doi.org/10.1029/ 2018GL079059

Received 1 JUN 2018

Accepted 27 AUG 2018

Accepted article online 4 SEP 2018

Published online 12 OCT 2018

C2018. American Geophysical Union. All Rights Reserved.

This article has been contributed to by US Government employees and their work is in the public domain in the USA.

\section{Major Volatiles Evolved From Eolian Materials in Gale Crater}

\author{
Jennifer C. Stern' iD, Brad Sutter ${ }^{2,3}$ iD, P. Douglas Archer ${ }^{2,3}$, Jennifer L. Eigenbrode ${ }^{1}$ iD, \\ Amy C. McAdam ${ }^{1}$ iD, Heather B. Franz ${ }^{1}$, Christine Knudson ${ }^{1,4}$ iD, Douglas W. Ming ${ }^{3}$ iD, \\ Gregory Wong ${ }^{5}$, Caroline Freissinet ${ }^{6}$, Charles A. Malespin ${ }^{1}$, Rafael Navarro-Gonzalez ${ }^{7}$ iD, \\ Cyril Szopa ${ }^{8}$ iD, and Paul R. Mahaffy ${ }^{1}$ iD
}

${ }^{1}$ NASA Goddard Space Flight Center, Greenbelt, MD, USA, ${ }^{2}$ Jacobs Technology, Houston, TX, USA, ${ }^{3}$ NASA Johnson Space Center, Houston, TX, USA, ${ }^{4}$ CRESST/UMCP, University of Maryland, College Park, MD, USA, ${ }^{5}$ Department of Geosciences, Pennsylvania State University, University Park, PA, USA, ${ }^{6}$ LATMOS-IPSL/CNRS, Guyancourt, France, ${ }^{7}$ Institito de Ciencias Nucleares, Universidad Nacional Autónoma de México, México City, Mexico, ${ }^{8}$ LATMOS, University Pierre et Marie Curie, University Versailles Saint-Quentin and CNRS, Paris, France

Abstract The Sample Analysis at Mars on the Curiosity rover analyzed the major volatile content of four eolian samples at three locations in Gale crater. The Rocknest sample was taken from an inactive sand shadow with a significant component of dust-sized grains, while Gobabeb and Ogunquit Beach samples were taken from different locations in the Bagnold Dune field and had dust-free, fine sand sized grains. All eolian samples possessed more oxychlorine, carbon, and nitrate relative to sedimentary materials in Gale crater. Evolved $\mathrm{CO}_{2}$ above $450{ }^{\circ} \mathrm{C}$ was consistent with $\sim 0.7$ and $\sim 0.4$ wt. \% carbonate in the Bagnold Dunes and Rocknest materials, respectively, with a regional source inside Gale crater. The fine-grained phase of Rocknest was enriched in adsorbed water and perhaps in Fe sulfate and Fe nitrate/nitrite compared to coarser Bagnold materials and was estimated to contain up to $\sim 0.1 \mathrm{wt}$. \% of organic carbon.

Plain Language Summary Wind-driven processes have been the dominant force shaping the landscape on Mars for the last 3 billion years. Sands from a Martian dune field were analyzed and compared to other deposits with smaller, dust-sized grains. Samples were heated to release gases and determine their composition, revealing that sandy and dusty samples contained more carbon than rock samples. Sand and dust contained more nitrogen and chlorine bearing molecules made in the atmosphere and grain surfaces, either because they are sitting on the surface accumulating them or because nitrogen and chlorine were removed from rocks in the past by water or other processes. Dusty samples had similar compositions to sandy samples and also contained phases associated only with the small dust grains, including adsorbed water. Dust appeared to contain simple organic carbon molecules, perhaps due to atmospheric and surface processes acting to break down more complex organic molecules in rocks. Sand appeared to contain more inorganic carbon in the form of carbonate, even though the rocks nearby do not contain carbonate. Because sand can only travel a limited distance, this suggests that carbonate is present in rocks somewhere in Gale crater that we have not explored yet.

\section{Introduction}

Orbital remote sensing of the dunes inside Gale crater prior to Mars Science Laboratory (MSL) rover landing indicated olivine basaltic composition (Rogers \& Bandfield, 2009), but the volatile inventory of eolian materials and their potential to be a repository for products of atmospheric chemistry has not been evaluated. Eolian processes have likely dominated the Martian landscape for the last $\sim 3 \mathrm{Ga}$, when liquid water was no longer widespread on Mars (Carr \& Head, 2010). Although eolian bedforms have been mapped from orbit (Hayward et al., 2012) and observed by the Mars Exploration Rovers (e.g., Sullivan et al., 2008), the MSL Bagnold Dune Field campaigns represent the first in situ investigation of an active dune field on Mars.

Eolian samples potentially record information about modern atmospheric processes and deposition of atmospheric species (e.g., $\mathrm{H}_{2} \mathrm{O}, \mathrm{Cl}_{x}\left(\mathrm{O}_{x}\right), \mathrm{N}_{2}$, and $\mathrm{CO}_{2}$ ) as well as processes involved in organic matter decomposition. Atmospheric and grain surface reactions are mechanisms proposed to drive oxychlorine production (Carrier \& Kounaves, 2015; Wilson et al., 2016) and have been implicated in the formation of fixed nitrogen (Mancinelli, 1996; Smith et al., 2014) and methane on Mars (Keppler et al., 2012). Exposure of organic-bearing sediments to photochemical and surface mediated processes were argued to result in oxidation of complex organics 
to simpler species (Benner et al., 2000). Surface materials, particularly those containing significant amounts of dust, which could remain in contact with the atmosphere, may therefore be a repository for the products of atmospheric chemistry operating over long timescales that are too dilute to directly measure in the atmosphere.

The overall goal of this work was to evaluate the content and sources of volatiles in Gale Crater eolian material by the Sample Analysis at Mars (SAM) instrument onboard MSL's Curiosity rover. Specifically, the objectives of this work were to (1) compare the concentrations and evolution temperatures of major volatiles from one dust-bearing and two sand dune eolian samples, (2) compare volatile characteristics of the eolian samples with sedimentary rock samples, and (3) utilize these results to provide insight into sources of water, chlorine, sulfur, nitrogen, and carbon detected in these materials.

\section{Sample Sites}

Eolian samples were acquired from two separate sand dune sites and one dust-bearing sand shadow. The sand dune material was derived from the informally designated Bagnold Dune Field that consists of an 30-km-long, 1- to 2-km-wide swath of active dunes. The Bagnold Dunes were characterized by barchan and barchanoidal dunes (Phase 1) and linear (Phase 2) dunes that unconformably overlay the Murray formation on the lower northwest flank of Aeolis Mons (informally known as Mount Sharp; Lapotre \& Rampe, 2018). Active Bagnold Dunes sands have a narrow grain size distribution representing very fine sand (100-150 $\mu \mathrm{m}$; Lapotre et al., 2016; Sullivan \& Kok, 2017; Weitz et al., 2018) and lack silt and dust-sized grains (Agnes et al., 2017; Weitz et al., 2018). Phase 1 occurred in southern fall/winter at a time of low dune activity (Bridges et al., 2017), while Phase 2 occurred in southern summer coincident with observations of high sand flux (Baker et al., 2018). In Phase 1, two samples were scooped from the Gobabeb site at Namib Dune, chosen based on engineering constraints and orbital data, and sieved to different grain sizes. Gobabeb 1 (GB1) consisted of material $<150 \mu \mathrm{m}$, which is the same size fraction of most solid samples analyzed thus far, whereas Gobabeb 2 (GB2) consisted of material $150 \mu \mathrm{m}$ to $1 \mathrm{~mm}$. Volatile abundances were not quantified for GB2 due to difficulties estimating the mass of sample acquired by SAM. The Phase 2 Ogunquit Beach (OG) sample $(<150 \mu \mathrm{m}$ ) occurred $\sim 2 \mathrm{~km}$ to the southwest of $\mathrm{GB}$ and was acquired downwind from a large body of windblown sand to minimize contributions from local bedrock. The sample was referred to as OG3 because it was the third sample delivered to SAM due to difficulties during previous sample delivery attempts.

Samples from Bagnold Dunes were compared to Rocknest (RN; Archer, Franz, et al., 2014; Leshin et al., 2013), an inactive eolian sand shadow (Blake et al., 2013). RN displayed a broad, bimodal grain size distribution with dust-sized grains $(<100-250 \mu \mathrm{m})$ coating coarser grains (0.5-2.2 mm; Minitti et al., 2013; Weitz et al., 2018). $\mathrm{RN}$ data are reported as an average of four individual analyses.

\section{Methods}

Data presented here were acquired using SAM's evolved gas analysis experiment (EGA; Mahaffy et al., 2012). A scooped sample was sieved ( $<150 \mu \mathrm{m}$ or $150 \mu \mathrm{m}$ to $1 \mathrm{~mm}$ ) and portioned by MSL's sample handling system. The sample was delivered to SAM's solid sample inlet into a preconditioned quartz cup (heated to $\sim 870{ }^{\circ} \mathrm{C}$ and cooled before delivery) and sealed into one of two SAM ovens. Prior to analysis, the SAM gas processing system was heated to $135^{\circ} \mathrm{C}$. Samples were heated at $\sim 35^{\circ} \mathrm{C} / \mathrm{min}$ to $\sim 870^{\circ} \mathrm{C}$ under helium flow $(\sim 0.8 \mathrm{sccm})$. Gases evolved during thermal decomposition of solid samples were continuously sampled by the mass spectrometer. Mass estimates for delivered sample portions were used to calculate the concentration of evolved gases in weight percent and part per million. Measurement error was derived from propagation of errors of both the sample mass estimate and evolved gas analysis. Additional data detailing molar abundance and quantification for all samples are in the supporting information (SI). Additional details of evolved gas quantification were described elsewhere (Archer, Franz, et al., 2014; Franz et al., 2014) while discussion of instrument background correction can be found in the SI and Glavin et al. (2013) and Freissinet et al. (2015).

\section{Results}

Water release occurred over a broad range of temperatures in Bagnold materials $\left(\sim 200-800^{\circ} \mathrm{C}\right)$ compared to $\mathrm{RN}$, which evolved most of its water below $500^{\circ} \mathrm{C}$ (Figure 1a). RN contained about twice as much water as the GB1 and OG3 samples (Table 1). Low-temperature water release at RN is consistent with water adsorbed to grain surfaces. The broad release of water between 300 and $500^{\circ} \mathrm{C}$ and above $600{ }^{\circ} \mathrm{C}$ in GB1 and GB2 has 

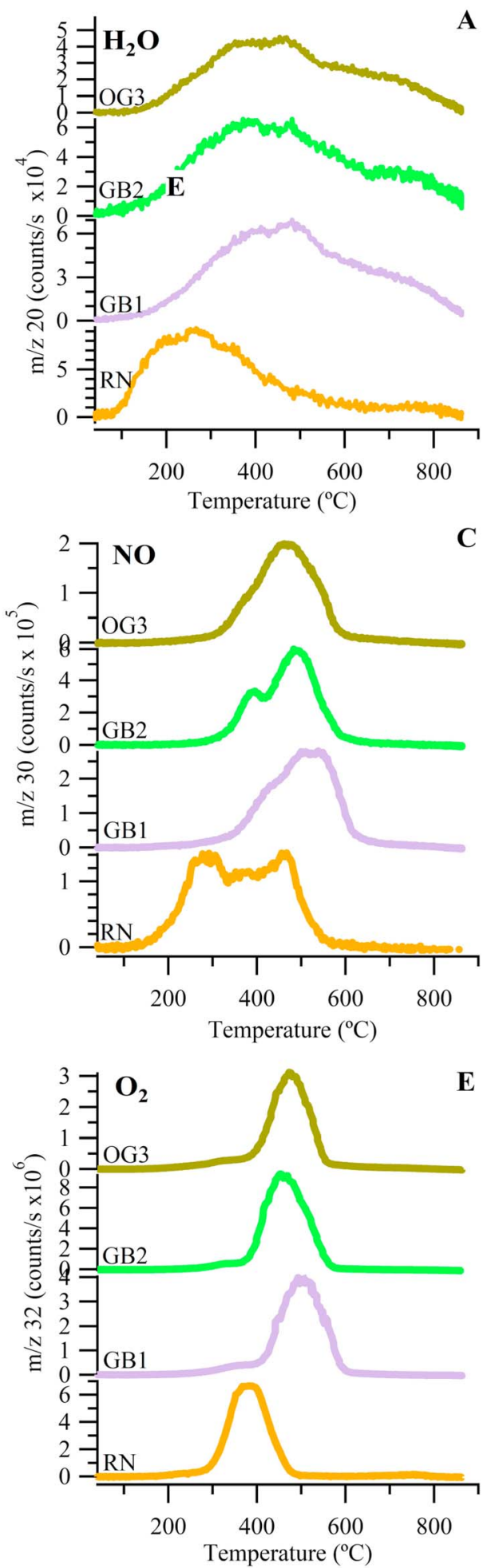
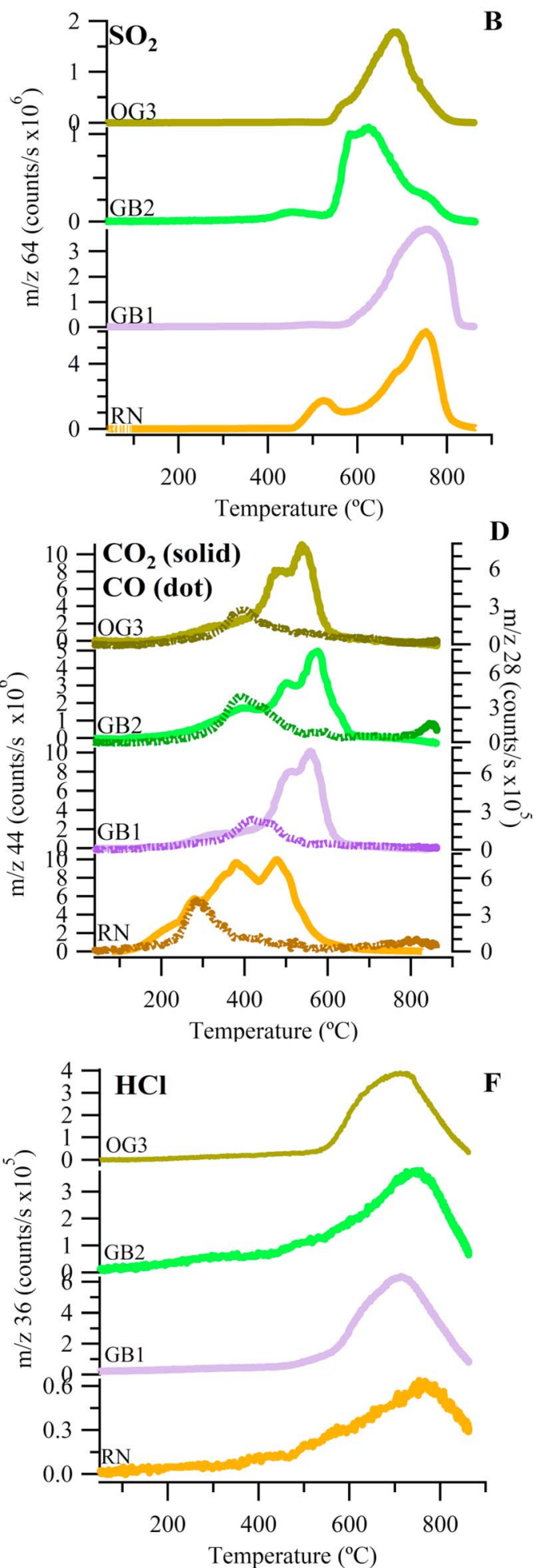

Figure 1. Evolved gas profiles for (a) $\mathrm{H}_{2} \mathrm{O}$, (b) $\mathrm{SO}_{2}$, (c) $\mathrm{NO}$, (d) $\mathrm{CO}$ and $\mathrm{CO}_{2}$, (e) $\mathrm{O}_{2}$, and (f) $\mathrm{HCl}$. $Y$ axes are scaled to optimize viewing for each species and vary accordingly. $\mathrm{OG}=$ Ogunquit Beach; $\mathrm{GB}=\mathrm{Gobabeb}$; $\mathrm{RN}=$ Rocknest.

been attributed to mineral or glass inclusions, hydrated salts, and/or hydroxyl-bearing phases (e.g., altered glass and Fe-oxyhydroxides; Ehlmann et al., 2017; Sutter et al., 2017). The OG3 profile shows the same broad releases at these temperatures, suggesting the same materials are present. 
Table 1

Abundance of Major Species in RN and Bagnold Scooped Samples

\begin{tabular}{|c|c|c|c|c|}
\hline & Unit & RNavg $^{\text {a }}$ (Sutter et al., 2017) & GB1 ${ }^{\mathrm{b}}$ (Sutter et al., 2017) & $O G 3^{b}$ \\
\hline $\mathrm{CO}_{2}{ }^{\mathrm{C}}$ & wt. \% & $0.8 \pm 0.2$ & $0.7 \pm 0.2$ & $0.4 \pm 0.2$ \\
\hline $\mathrm{SO}_{3}$ & wt. \% & $2.0 \pm 2.2$ & $1.2 \pm 0.3$ & $0.3 \pm 0.1$ \\
\hline $\mathrm{SO}_{3} \mathrm{APXS}$ & wt. \% & $5.5 \pm 2.2$ & $3.3 \pm 0.5$ & $3.4 \pm 0.1$ \\
\hline $\mathrm{H}_{2} \mathrm{O}$ & wt. \% & $2.0 \pm 1.3$ & $1.1 \pm 0.5$ & $0.8 \pm 0.3$ \\
\hline $\mathrm{ClO}_{4}^{-\mathrm{d}}$ & wt. \% & $0.36 \pm 0.15$ & $0.21 \pm 0.06$ & $0.15 \pm 0.04$ \\
\hline $\mathrm{Cl}_{-} \mathrm{ClO}_{4}^{-}$ & ppm & $1,288 \pm 541$ & $731 \pm 199$ & $528 \pm 141$ \\
\hline $\mathrm{Cl}-\mathrm{HCl}$ & ppm & $39 \pm 53$ & $614 \pm 378$ & $453 \pm 230$ \\
\hline CI APXS & ppm & $6,900 \pm 2,100$ & $5300 \pm 90$ & $5700 \pm 200$ \\
\hline $\mathrm{H}_{2}$ & ppm & $120 \pm 30$ & $27 \pm 8$ & $107 \pm 36$ \\
\hline $\mathrm{H}_{2} \mathrm{~S}$ & ppm & $76 \pm 36$ & $47 \pm 16$ & $22 \pm 7$ \\
\hline $\mathrm{NO}_{3}{ }^{\mathrm{C}}$ & ppm & $263 \pm 67$ & $277 \pm 72$ & $168 \pm 48$ \\
\hline $\mathrm{CO}$ & ppm & $91 \pm 15$ & $17 \pm 4$ & $69 \pm 16$ \\
\hline
\end{tabular}

Note. Selected APXS data included for comparison from Schmidt et al. (2014) for Rocknest (RN) and O'Connell-Cooper et al. (2017) for Gobabeb (GB). OG = Ogunquit Beach.

${ }^{a}$ Reported as an average and standard deviation of four samples. ${ }^{b}$ Error represents instrument precision. ${ }^{c}$ Corrected for minor components of instrument background; see SM for details. ${ }^{d} \mathrm{ClO}_{4}{ }^{-}$data calculated from oxygen abundance below $600{ }^{\circ} \mathrm{C}$. Nitrate contribution to oxygen has been removed. Perchlorate $\left(\mathrm{ClO}_{4}{ }^{-}\right)$concentration is presented for simplicity; however, it is noted that chlorate $\left(\mathrm{ClO}_{3}{ }^{-}\right)$may also be present in some samples.

$\mathrm{SO}_{2}$ evolutions vary between samples (Figure $1 \mathrm{~b}$ ), particularly between $\mathrm{GB} 1$ and $\mathrm{GB} 2$, suggesting differing distributions of sulfur bearing species amongst eolian materials, possibly correlated with grain size. RN, GB1, and OG3 had a somewhat similar release between 600 and $800{ }^{\circ} \mathrm{C}$, consistent with $\mathrm{Mg}$ sulfate (McAdam et al., 2014; Sutter et al., 2017). $\mathrm{SO}_{2}$ evolution in GB2 (150 $\mu \mathrm{m}$ to $1 \mathrm{~mm}$ ) was skewed to slightly lower temperatures and may represent a mixture of $\mathrm{Mg}$ sulfate and Fe sulfate, which thermally decomposes between approximately $500-650{ }^{\circ} \mathrm{C}$ (McAdam et al., 2014; Sutter et al., 2017). Small $\mathrm{SO}_{2}$ evolutions in the $500-650^{\circ} \mathrm{C}$ range from $\mathrm{RN}$ and $\mathrm{OG} 3$ may indicate minor Fe sulfate in those samples in addition to the more dominant phase evolving $\mathrm{SO}_{2}$ at higher temperature (likely Mg sulfate). SAM abundance data (Table 1) indicate that $\mathrm{RN}$ had twice as much $\mathrm{SO}_{3}$ as $\mathrm{GB} 1$, consistent with enrichment of sulfate in the dust-sized phase at RN. OG3 had four times less $\mathrm{SO}_{3}$ than GB1 based on SAM analysis, although APXS data detect similar amounts of $\mathrm{SO}_{3}$ in both samples (Table 1 ).

NO evolved between 350 and $600{ }^{\circ} \mathrm{C}$ in OG3, similar to GB1 and GB2 (Figure 1c), and was consistent with the decomposition of Mg nitrate (Gordon \& Campbell, 1955; Mu \& Perlmutter, 1982; Stern et al., 2015) or any nitrate salt in the presence of $\mathrm{Mg}$ perchlorate and chlorate (Navarro-González et al., 2018). NO starts evolving at $\mathrm{RN}$ at lower temperatures $\left(150{ }^{\circ} \mathrm{C}\right)$ than other eolian samples and may comprise more than one nitrate species (Stern et al., 2015). Lower temperature evolutions (150$350{ }^{\circ} \mathrm{C}$ ) suggest the presence of Fe nitrate (Gordon \& Campbell, 1955; Mu \& Perlmutter, 1982; Stern et al., 2015) and/or nitrites (Navarro-González et al., 2018). The early evolution of NO at RN likely associated with the dust phase may represent a different nitrate species $\left(\mathrm{FeNO}_{3}\right)$ than found in coarser materials, for which $\mathrm{NO}$ evolutions suggest $\mathrm{Mg}$ nitrate as the primary nitrate phase. Abundances in all eolian materials are similar (Table 1).

$\mathrm{CO}_{2}$ release profiles in Bagnold Dune materials show one broad peak between 200 and $450{ }^{\circ} \mathrm{C}$ and two sharper peaks above $450{ }^{\circ} \mathrm{C}$ (Figure 1d). The $\mathrm{RN} \mathrm{CO}_{2}$ release starts at much lower temperatures, potentially due to the greater degree of fine materials here absorbing atmospheric $\mathrm{CO}_{2}$ or due to the presence of nanophase carbon bearing materials (e.g., carbonates) that evolve $\mathrm{CO}_{2}$ at lower temperatures (Archer, Lauer, et al., 2014). $\mathrm{CO}_{2}$ evolved from eolian materials could have multiple sources such as carbonate minerals, combustion products of organics, and products from the thermal decomposition of small organic salts such as Fe or Mg oxalates or acetates (Sutter et al., 2017) present as decomposition products of larger organic molecules (e.g., Benner et al., 2000).

$\mathrm{CO}$ evolutions in $\mathrm{OG} 3, \mathrm{~GB} 1$, and GB2 were similar and may be due to the decarboxylation of oxalates or partial oxidation of other organics in the sample or from instrument background. CO (Figure 1d) evolved below $450{ }^{\circ} \mathrm{C}$, at lower temperatures than the majority of the $\mathrm{CO}_{2}$ in each sample. However, there is some 


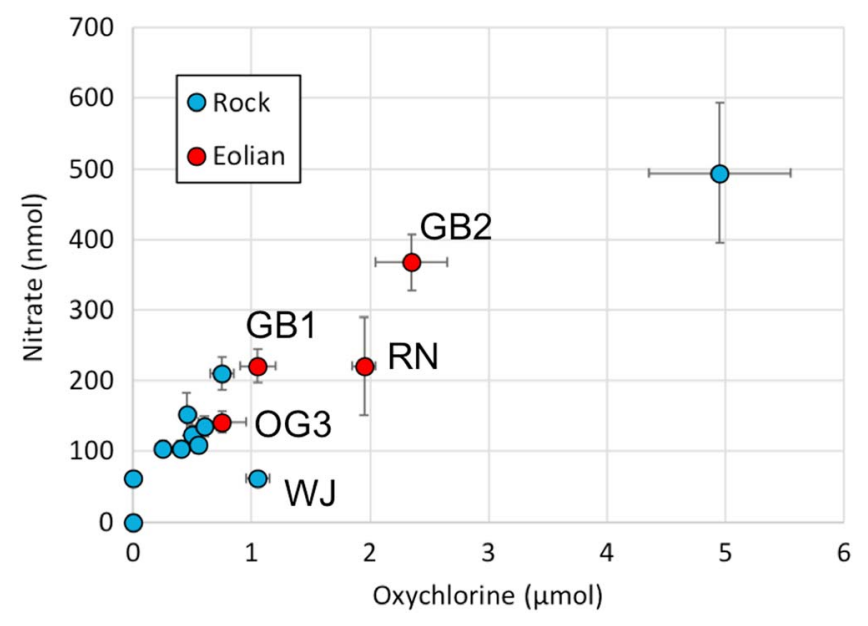

Figure 2. Nitrate abundance in eolian materials is greater than in most sedimentary rocks. Elevated values at $\mathrm{CB}$ likely reflect postdepositional processes. $\mathrm{OG}=$ Ogunquit Beach; GB = Gobabeb; RN = Rocknest; WJ = Windjana. overlap of $\mathrm{CO}$ evolution with $\mathrm{CO}_{2}$ evolved at $\mathrm{RN}, \mathrm{GB}$, and $\mathrm{OG}$ below $450^{\circ} \mathrm{C}$, which may indicate $\mathrm{CO}$ and $\mathrm{CO}_{2}$ were derived from a similar source (e.g., organics and carboxyls).

$\mathrm{O}_{2}$ in all Bagnold Dune samples evolved between 400 and $600{ }^{\circ} \mathrm{C}$ (Figure 1e) and was consistent with oxychlorine (e.g., chlorate and perchlorate). $\mathrm{HCl}$ evolution at high temperatures (Figure 1f) has been attributed to water vapor reacting with chlorine from decomposition of chloride salts, which are likely thermal decomposition products of the oxychlorine phases, as well as chloride salts already present in Gale surface materials (Sutter et al., 2017). Chlorine measured by SAM (Table 1) was quantified both indirectly and directly using two products of perchlorate decomposition. $\mathrm{Cl}_{-} \mathrm{ClO}_{4}{ }^{-}$concentration was inferred from evolved $\mathrm{O}_{2}$, while $\mathrm{Cl}-\mathrm{HCl}$ produced during this reaction was evolved above $\sim 600{ }^{\circ} \mathrm{C}$ and was directly measured (Figure 1e). $\mathrm{Cl}_{-} \mathrm{ClO}_{4}{ }^{-}$and $\mathrm{Cl}-\mathrm{HCl}$ were both always lower than total $\mathrm{Cl}$ measured by APXS. This is consistent with the presence of non-oxychlorine $\mathrm{Cl}$ associated with the amorphous and/or a trace crystalline phase, such as $\mathrm{NaCl}$ or $\mathrm{CaCl}_{2}$ (Sutter et al., 2017).

\section{Discussion}

Grain size variation between RN and the Bagnold samples was likely the cause of the differences in the observed water release profiles. RN contained a large fraction of fine-grained material ( $75 \%$ at $<100 \mu \mathrm{m}$ ) consistent with dust and silt sized grains (Minitti et al., 2013). The finer grained materials at RN have higher surface area and, therefore, more adsorption potential, which leads to the higher water content and the lower release temperature. Dust may also have structural water or hydroxylated surfaces that release water at lower temperatures. The GB and OG3 water releases are consistent with lower surface area materials analyzed in the laboratory, such as crushed basalt (McAdam et al., 2017).

While SAM detected Mg and Fe sulfates in eolian materials, APXS analyses showed greater $\mathrm{SO}_{3}$ content than could be accounted for by $\mathrm{SO}_{3}$ derived from SAM evolved $\mathrm{SO}_{2}$ data $\left(\mathrm{O}^{\prime}\right.$ Connell-Cooper et al., 2017; Schmidt et al., 2014). This is likely due to the presence of Ca sulfate minerals in these samples (Achilles et al., 2017; Rampe et al., 2018; Vaniman et al., 2014), which do not evolve $\mathrm{SO}_{2}$ in the SAM temperature range (Knudson et al., 2018; McAdam et al., 2015; Sutter et al., 2017). Ca sulfate is likely sourced from the pervasive $\mathrm{CaSO}_{4}$ veins in local bedrock encountered by Curiosity in Gale crater (Nachon et al., 2017). Although CheMin did not detect sulfides above its detection limit ( 1\%), Fe sulfides may be present and contribute to the SAM evolved $\mathrm{SO}_{2}$, for example, pyrrhotite, as suggested for RN (Bish et al., 2013), which releases $\mathrm{SO}_{2}$ in the 500$600{ }^{\circ} \mathrm{C}$ range in the presence of perchlorates (Ming et al., 2014).

Nitrate and oxychlorine concentrations are greater in Bagnold Dunes materials and in RN than in most sedimentary rock materials analyzed so far in Gale Crater (Figure 2). In terms of abundance, eolian samples appear to have intermediate concentrations of nitrate (150-300 ppm) compared to most samples analyzed by SAM, which generally have $<200$ ppm nitrate (Stern et al., 2017). Cumberland, a mudstone from the Yellowknife Bay unit which was deemed to be a habitable environment (Grotzinger et al., 2014), was the only sample with a higher nitrate concentration at $681 \pm 304$ ppm nitrate (Stern et al., 2017). These chemical species vary in the Murray formation samples and are present at particularly low concentrations (or absent altogether in the case of oxychlorine) in the nearby Marimba and Oudam sedimentary rock samples (Stern et al., 2017). One reason for this may be that, although these surface materials are active, their exposure to the atmosphere allows them to accumulate nitrate and oxychlorine, which at some point in time formed by photochemical and radiolytic mechanisms (Carrier \& Kounaves, 2015; Catling et al., 2010; Wilson et al., 2016). Similar to Mars, terrestrial nitrate, chlorate, and perchlorate formation through atmospheric and surface-atmospheric reactions will permit accumulation of these soluble phases in hyper-arid environments where precipitation is limited (Jackson et al., 2015, 2016; Lybrand et al., 2016). While the rates of nitrate or oxychlorine production in the modern Martian atmosphere are unknown, Bagnold dune materials have likely been exposed for millions, if not billions, of years, and even slow production of these species could result in modest enrichment in 
the surface materials. Another explanation for the absence of these species in nearby bedrock could be removal by fluvial processes or temporal variations in deposition.

Nitrate and oxychlorine have been shown to be correlated on Mars (Stern et al., 2017) as they are in hyperarid environments on Earth (e.g., Jackson et al., 2015). When plotted with Gale crater sedimentary rocks (Figure 2), there is an apparent enrichment in oxychlorine in Bagnold Dunes materials and RN. Eolian samples generally had 0.3-0.7 wt. \% $\mathrm{O}_{2}\left(0.15-0.36 \mathrm{wt}\right.$. $\% \mathrm{ClO}_{4}{ }^{-}$), while sedimentary rocks (with the exception of Cumberland in Yellowknife Bay) ranged from having no detectable $\mathrm{O}_{2}$ to $0.46 \mathrm{wt} . \% \mathrm{O}_{2}\left(0.23 \mathrm{wt}\right.$. $\% \mathrm{ClO}_{4}{ }^{-}$; Sutter et al., 2017). While GB1 and RN had comparable amounts of nitrate, RN appears to have more oxychlorine than GB1 or OG3 (Figure 2). This is consistent with ChemCam observations of enriched $\mathrm{Cl}$ in the dust phase (Lasue et al., 2018) and is likely due to the large component of dust in RN. This enrichment in oxychlorine over nitrate was observe at Windjana (WJ), an ancient cross-stratified sandstone consisting of fluvial sand reworked by eolian processes (Grotzinger et al., 2015; Treiman et al., 2016). Oxychlorine enrichment in the WJ sample may be due to subaerial exposure of WJ materials prior to lithification and burial. This would suggest that nitrate may not have been produced at the same rate as oxychlorine at the time of deposition of WJ, or was destroyed or removed.

Eolian materials differ from sedimentary rocks in Gale crater in both the concentrations and evolution temperatures of $\mathrm{CO}_{2} \cdot \mathrm{CO}_{2}$ evolved from all Bagnold samples at higher concentration (0.4 to 0.8 wt. \%) than local bedrock (0.1 to 0.4 wt. \%; Ehlmann et al., 2008; Sutter et al., 2017). In addition, the majority of $\mathrm{CO}_{2}$ was evolved above $450{ }^{\circ} \mathrm{C}$ (Figure $1 \mathrm{~d}$ ) in all three eolian samples, while most sedimentary rocks investigated thus far released $\mathrm{CO}_{2}$ below $450{ }^{\circ} \mathrm{C}$ (Sutter et al., 2017). The Bagnold Phase 2 eolian sample, $\mathrm{OG} 3$, contained less $\mathrm{CO}_{2}$ than other eolian samples but shows the same evolution temperatures as the GB samples.

Thermal decomposition techniques such as stepped pyrolysis and combustion coupled with gas chromatography and/or isotopic analysis have been widely used in terrestrial (e.g., Gilmour \& Pillinger, 1985) and meteorite studies (e.g., Sephton, 2012) to identify organic and inorganic carbonaceous components. In general, carbonate evolves $\mathrm{CO}_{2}$ from 500 to $900^{\circ} \mathrm{C}$ in SAM-like EGA analyses (e.g., Sutter et al., 2012), depending on mineralogy. However, for in situ EGA experiments on Mars (e.g., Leshin et al., 2013), distinguishing the source of evolved $\mathrm{CO}_{2}$ has been complicated by the presence of oxychlorine, which provides oxygen to combust low and middle molecular weight organics in the sample below $600{ }^{\circ} \mathrm{C}$. In addition, $\mathrm{HCl}$ generated by decomposition of oxychlorine can drive carbonate decomposition temperatures down by $100{ }^{\circ} \mathrm{C}$ or more (Cannon et al., 2012; see also SI), into the range of temperatures typically expected for combustion of organics. Therefore, assignments of organic and inorganic to our $\mathrm{CO}_{2}$ releases must be considered best guesses.

The $\mathrm{CO}_{2}$ evolution temperatures and lack of corresponding $\mathrm{CO}$ peak above $450{ }^{\circ} \mathrm{C}$ in $\mathrm{GB}$ and $\mathrm{OG} 3$ are consistent with $\mathrm{CO}_{2}$ evolutions of $\mathrm{Mg}$ and Fe carbonate in the presence of oxychlorine in SAM-like laboratory experiments (SI). However, other potential interpretations include complete combustion of organic molecules to $\mathrm{CO}_{2}$ by $\mathrm{O}_{2}$ released over this temperature range by perchlorate decomposition, including a small contribution from combustion of organics from the instrument background (Eigenbrode et al., 2018). Combustion of instrument background is estimated in the $\mathrm{SI}$, and only makes up a minor component of the total evolved $\mathrm{CO}_{2}$ (see $\mathrm{SI}$ ). At RN, the $\mathrm{CO}_{2}$ evolutions between 350 and $600{ }^{\circ} \mathrm{C}$ suggest Fe carbonates (Leshin et al., 2013; Sutter et al., 2017), although some contribution from organic phases cannot be ruled out, particularly below $500{ }^{\circ} \mathrm{C}$. Furthermore, enriched $\delta^{13} \mathrm{C}$ values of $\mathrm{CO}_{2}$ evolved above $350{ }^{\circ} \mathrm{C}$ compared to $\mathrm{CO}_{2}$ evolved below $350^{\circ} \mathrm{C}$ in RN materials reported in Leshin et al. (2013) have been used to support the presence of carbonate above $350^{\circ} \mathrm{C}$ and organics below $350^{\circ} \mathrm{C}$ (Leshin et al., 2013).

A small amount of $\mathrm{CO}_{2}$ was evolved below $450{ }^{\circ} \mathrm{C}$ in Bagnold Dunes samples and overlapped with $\mathrm{CO}$ between $\sim 300$ and $450{ }^{\circ} \mathrm{C}$, potentially suggesting incomplete combustion of an organic source. This could include indigenous Martian organics, organics from infall of meteoritic material, or instrument contamination (or a mixture of these). The first SAM derivatization experiment was performed on OG materials (Malespin et al., 2018) and will provide insight into any complex organics present. In addition, decarboxylation of simple carboxylic acids such as oxalates has been suggested as a source of evolved $\mathrm{CO}_{2}$ on Mars (Applin et al., 2015; Benner et al., 2000; Eigenbrode et al., 2014; Sutter et al., 2017). These oxalates could form as a product of Fenton-like reactions in the presence of UV radiation in the Martian atmosphere or on the surface (Benner et al., 2000). 


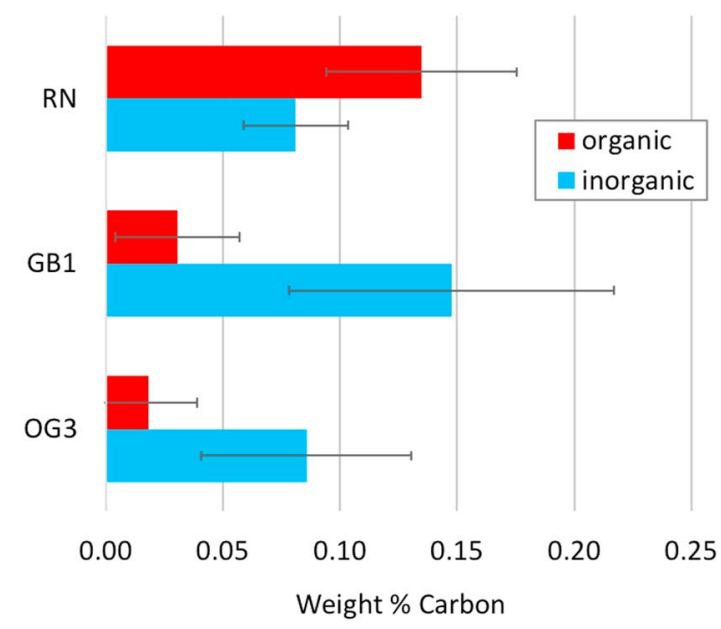

Figure 3. Estimates of inorganic and organic carbon in Bagnold Dune sands GB1 and OG3, and RN sand shadow. OG = Ogunquit Beach; GB = Gobabeb; $\mathrm{RN}=$ Rocknest.
If we hypothesize that $\mathrm{CO}_{2}$ evolved above $450{ }^{\circ} \mathrm{C}$ was from carbonate, and $\mathrm{CO}_{2}$ evolved below $450{ }^{\circ} \mathrm{C}$ was derived from organic sources, weight percentage of inorganic carbon (e.g., carbonate) and organic carbon can be estimated in these samples (Figure 3). Bagnold Dune samples GB1 and OG3 were estimated to have $0.15 \pm 0.06$ and $0.09 \pm 0.03$ wt. \% inorganic $C$, respectively. This corresponds to $0.74 \pm 0.30$ and $0.43 \pm 0.17 \mathrm{wt}$. \% carbonate, respectively. RN has $0.08 \pm 0.02$ wt. \% inorganic C, or $0.41 \pm 0.11$ wt. \% carbonate. These carbonate concentrations are below the detection limit $(\sim 1 \%)$ of the CheMin instrument. Carbonate detected on Mars has been traditionally associated with dust (Bandfield et al., 2003) but has also been detected in rocks on the outcrop to regional scale (Ehlmann et al., 2008; Morris et al., 2010). Carbonate detected in Mars surface materials is not unexpected, although if carbonate primarily exists in dust, carbonate would be expected to be more abundant in $\mathrm{RN}$ than in GB1 and OG3. If carbonate is present in the very fine sand $(100-150 \mu \mathrm{m})$ size fraction of Bagnold sands, this suggests that the source of carbonate must be sedimentary rock within Gale crater, and not global dust.

Organic carbon in Bagnold Dunes samples is within the error of the measurement $(0.03 \pm 0.15$ wt. \% at OG3 and $0.02 \pm 0.09$ wt. $\%$ at GB1). RN, in contrast to Bagnold, appears to have organic carbon above measurement error $(0.13 \pm 0.08$ wt. \%), which could originate from combustion or decarboxylation of small organic salts such as Fe or Mg oxalates or acetates (Sutter et al., 2017), but is unlikely to originate from the instrument itself (as this has already been subtracted from the total carbon). The difference between RN and Bagnold Dunes samples may indicate that the dust phase at RN is the reservoir for the organics in eolian material.

\section{Conclusions}

Volatile compositions of eolian materials sampled at OG3 in Phase 2 of the Bagnold Dunes campaign are similar to those sampled in Phase 1, with similar water, nitrogen, oxygen, chlorine, carbon, and perhaps sulfur bearing species. OG3 is slightly depleted in volatiles compared to both GB1 and RN, particularly in $\mathrm{SO}_{2}$. Differences in the temperature of volatile evolutions at $\mathrm{RN}$ compared to Bagnold Dune Field appear to be primarily due to differences in dust content. The fine-grained phase of RN is enriched in adsorbed water and perhaps in Fe sulfate and Fe nitrate/nitrate compared to coarser Bagnold materials, which are more $\mathrm{Mg}$ rich, based on differences in evolution temperatures. $\mathrm{CO}_{2}$ and $\mathrm{CO}$ evolve at lower temperatures in $\mathrm{RN}$, either due to their evolution from finer grained carbon bearing phases or different carbon bearing phases.

The Bagnold Dune materials likely represent a regional source within Gale Crater, with little contribution from global dust. These materials are distinct from RN eolian materials, which perhaps represent global contributions. The presence of evolved $\mathrm{CO}_{2}$ above $450^{\circ} \mathrm{C}$ thought to originate from thermal decomposition of carbonate sets Bagnold eolian samples apart from sedimentary rocks in Gale crater. This is intriguing because this carbonate is present in the relatively dust-free Bagnold Dune sands but not in most Gale crater sedimentary rocks analyzed thus far, suggesting a regional source of carbonate somewhere inside of Gale crater. Enrichment of $\mathrm{CO}_{2}, \mathrm{NO}$, and $\mathrm{O}_{2}$ in eolian materials with respect to sedimentary samples in Gale crater could be due to accumulation of nitrates, oxychlorine, and organic carbon (e.g., oxalate and organic salts) formed by photochemical and grain surface processes in the Martian atmosphere. The fact that Bagnold eolian materials enriched in nitrate and oxychlorine are located geographically near other samples analyzed by Curiosity in which both species are absent suggests either removal of these species from sedimentary rocks or temporal variations in their deposition. The question of whether these species are currently being created by surface-atmosphere interactions or are the product of relic atmospheric processes motivates the need for isotope measurements such as ${ }^{15} \mathrm{~N}$ in nitrates, as well as a better understanding of the exposure ages of surface materials. 
Acknowledgments

SAM data are available at the planetary data system: http://pds285geosciences. wustl.edu/missions $/ \mathrm{msl} / \mathrm{sam}$.htm. The authors thank the MSL Eolian Working Group and SAM and MSL Engineering, Science, and Operations teams for successful operation of the SAM instrument and Curiosity Rover during the Bagnold Dunes campaign. This research is supported by the NASA Mars Exploration Program.

\section{References}

Achilles, C. N., Downs, R. T., Ming, D. W., Rampe, E. B., Morris, R. V., Treiman, A. H., et al. (2017). Mineralogy of an active eolian sediment from the Namib dune, Gale crater, Mars. Journal of Geophysical Research: Planets, 122, 2344-2361. https://doi.org/10.1002/2017JE005262

Agnes, C., Erwin, D., Pierre-Yves, M., Olivier, F., Williams, A. J., Nathan, S., et al. (2017). Geochemistry of the Bagnold dune field as observed by ChemCam and comparison with other aeolian deposits at Gale Crater. Journal of Geophysical Research: Planets, 122, $2144-2162$. https://doi.org/10.1002/2017JE005261

Applin, D. M., Izawa, M. R. M., Cloutis, E. A., Goltz, D., \& Johnson, J. R. (2015). Oxalate minerals on Mars? Earth and Planetary Science Letters, 420 127-139. https://doi.org/10.1016/j.epsl.2015.03.034

Archer, P. D., Franz, H. B., Sutter, B., Arevalo, R. D., Coll, P., Eigenbrode, J. L., et al. (2014). Abundances and implications of volatile-bearing species from evolved gas analysis of the Rocknest aeolian deposit, Gale Crater, Mars. Journal of Geophysical Research: Planets, 119, $237-254$. https://doi.org/10.1002/2013JE004493

Archer, P. D., Lauer, H., Ming, D., Niles, P., Morris, R., Rampe, E. \& Sutter, B. (2014). Nanophase carbonates on Mars: Formation, detection, and implications, in Lunar and Planetary Science Conference, edited, p. 1075.

Baker, M., Lapotre, M., Minitti, M., Newman, C., Sullivan, R., Weitz, C., et al. (2018). The Bagnold dunes in southern summer: Active sediment transport on Mars observed by the Curiosity rover. Geophysical Research Letters, 45. https://doi.org/10.1029/2018GL079040

Bandfield, J. L., Glotch, T. D., \& Christensen, P. R. (2003). Spectroscopic identification of carbonate minerals in the Martian dust. Science, 301(5636), 1084-1087. https://doi.org/10.1126/science.1088054

Benner, S. A., Devine, K. G., Matveeva, L. N., \& Powell, D. H. (2000). The missing organic molecules on Mars. Proceedings of the National Academy of Sciences, 97(6), 2425-2430. https://doi.org/10.1073/pnas.040539497

Bish, D. L., Blake, D. F., Vaniman, D. T., Chipera, S. J., Morris, R. V., Ming, D. W., et al. (2013). X-ray diffraction results from Mars Science Laboratory: Mineralogy of Rocknest at Gale Crater. Science, 341(6153), 1238932. https://doi.org/10.1126/science.1238932

Blake, D. F., Morris, R. V., Kocurek, G., Morrison, S. M., Downs, R. T., Bish, D., et al. (2013). Curiosity at Gale Crater, Mars: Characterization and analysis of the Rocknest sand shadow. Science, 341(6153), 1239505. https://doi.org/10.1126/science.1239505

Bridges, N., Sullivan, R., Newman, C., Navarro, S., Van Beek, J., Ewing, R., et al. (2017). Martian aeolian activity at the Bagnold Dunes, Gale crater The view from the surface and orbit. Journal of Geophysical Research: Planets, 122, 2077-2110. https://doi.org/10.1002/2017JE005263

Cannon, K., Sutter, B., Ming, D., Boynton, W., \& Quinn, R. (2012). Perchlorate induced low temperature carbonate decomposition in the Mars Phoenix Thermal and Evolved Gas Analyzer (TEGA). Geophysical Research Letters, 39, L13203. https://doi.org/10.1029/2012GL051952

Carr, M. H., \& Head, J. W. (2010). Geologic history of Mars. Earth and Planetary Science Letters, 294(3-4), 185-203. https://doi.org/10.1016/j.epsl.2009.06.042

Carrier, B. L., \& Kounaves, S. P. (2015). The origins of perchlorate in the Martian soil. Geophysical Research Letters, 42, 3739-3745. https://doi. org/10.1002/2015GL064290

Catling, D., Claire, M., Zahnle, K., Quinn, R., Clark, B., Hecht, M., \& Kounaves, S. (2010). Atmospheric origins of perchlorate on Mars and in the Atacama. Journal of Geophysical Research, 115, E00E11. https://doi.org/10.1029/2009JE003425

Ehlmann, B. L., Edgett, K. S., Sutter, B., Achilles, C. N., Litvak, M. L., Lapotre, M. G. A., et al. (2017). Chemistry, mineralogy, and grain properties at Namib and High dunes, Bagnold dune field, Gale crater, Mars: A synthesis of curiosity rover observations. Journal of Geophysical Research: Planets, 122, 2510-2543. https://doi.org/10.1002/2017JE005267

Ehlmann, B. L., Mustard, J. F., Murchie, S. L., Poulet, F., Bishop, J. L., Brown, A. J., et al. (2008). Orbital identification of carbonate-bearing rocks on Mars. Science, 322(5909), 1828-1832. https://doi.org/10.1126/science.1164759

Eigenbrode, J., Bower, H., \& Archer Jr, P. (2014). Decarboxylation of carbon compounds as a potential source for $\mathrm{CO}_{2}$ and $\mathrm{CO}_{\text {observed by SAM at }}$ Yellowknife Bay, Gale Crater, Mars, in 45th Lunar and Planetary Science Conference, edited, p. 1605, Lunar and Planetary Institute, Houston.

Eigenbrode, J. L., Summons, R. E., Steele, A., Freissinet, C., Millan, M. v., \& Navarro-González, R., et al. (2018). Organic matter preserved in 3-billion-year-old mudstones at Gale crater, Mars. Science, 360(6393), 1096-1101. https://doi.org/10.1126/science.aas9185

Franz, H. B., Trainer, M. G., Wong, M. H., Manning, H. L., Stern, J. C., Mahaffy, P. R., et al. (2014). Analytical techniques for retrieval of atmospheric composition with the quadrupole mass spectrometer of the Sample Analysis at Mars instrument suite on Mars Science Laboratory. Planetary and Space Science, 96, 99-113. https://doi.org/10.1016/j.pss.2014.03.005

Freissinet, C., Glavin, D. P., Mahaffy, P. R., Miller, K. E., Eigenbrode, J. L., Summons, R. E., et al. (2015). Organic molecules in the Sheepbed Mudstone, Gale Crater, Mars. Journal of Geophysical Research: Planets, 120, 495-514. https://doi.org/10.1002/2014JE004737

Gilmour, I., \& Pillinger, C. T. (1985). Stable carbon isotopic analysis of sedimentary organic matter by stepped combustion. Organic Geochemistry, 8(6), 421-426. https://doi.org/10.1016/0146-6380(85)90020-8

Glavin, D. P., Freissinet, C., Miller, K. E., Eigenbrode, J. L., Brunner, A. E., Buch, A., et al. (2013). Evidence for perchlorates and the origin of chlorinated hydrocarbons detected by SAM at the Rocknest aeolian deposit in Gale Crater. Journal of Geophysical Research: Planets, 118, 1955-1973. https://doi.org/10.1002/jgre.20144

Gordon, S., \& Campbell, C. (1955). Differential thermal analysis of inorganic compounds. Analytical Chemistry, 27(7), 1102-1109. https://doi. org/10.1021/ac60103a018

Grotzinger, J. P., Gupta, S., Malin, M. C., Rubin, D. M., Schieber, J., Siebach, K., et al. (2015). Deposition, exhumation, and paleoclimate of an ancient lake deposit, Gale crater, Mars. Science, 350(6257), aac7575. https://doi.org/10.1126/science.aac7575

Grotzinger, J. P., Sumner, D., Kah, L., Stack, K., Gupta, S., Edgar, L., et al. (2014). A habitable fluvio-lacustrine environment at Yellowknife Bay, Gale crater, Mars. Science, 343(6169), 1242777. https://doi.org/10.1126/science.1242777

Hayward, R. K., Fenton, L. K., Titus, T. N., Colaprete, A., \& Christensen, P. R. (2012). Mars global digital dune database: MC-30Rep., U.S. Geological Survey

Jackson, W. A., Bohlke, J. K., Andraski, B. J., Fahlquist, L., Bexfield, L., Eckardt, F. D., et al. (2015). Global patterns and environmental controls of perchlorate and nitrate co-occurrence in arid and semi-arid environments. Geochimica et Cosmochimica Acta, 164, 502-522. https://doi. org/10.1016/j.gca.2015.05.016

Jackson, W. A., Davila, A. F., Böhlke, J. K., Sturchio, N. C., Sevanthi, R., Estrada, N., et al. (2016). Deposition, accumulation, and alteration of Cl-, $\mathrm{NO} 3-, \mathrm{ClO} 4-$ and $\mathrm{ClO} 3$ - salts in a hyper-arid polar environment: Mass balance and isotopic constraints. Geochimica et Cosmochimica Acta, 182, 197-215. https://doi.org/10.1016/j.gca.2016.03.012

Keppler, F., Vigano, l., McLeod, A., Ott, U., Früchtl, M., \& Röckmann, T. (2012). Ultraviolet-radiation-induced methane emissions from meteorites and the Martian atmosphere. Nature, 486(7401), 93-96. https://doi.org/10.1038/nature11203

Knudson, C., Perrett, G., McAdam, A., Campbell, J., Flannigan, E., Morris, R., et al. (2018). Investigation of mineral phase effects caused by sulfur bearing minerals in a Cumberland Simulant, using laboratory equivalents of SAM, APXS, and CheMin Mars Science Laboratory Instruments, in Lunar and Planetary Science Conference, edited, p. 2316.

Lapotre, M., Ewing, R., Lamb, M., Fischer, W., Grotzinger, J., Rubin, D., et al. (2016). Large wind ripples on Mars: A record of atmospheric evolution. Science, 353(6294), 55-58. https://doi.org/10.1126/science.aaf3206 
Lapotre, M. G. A., \& Rampe, E. B. (2018). Curiosity's investigation of the Bagnold dunes, Gale crater: Overview of the two-phase scientific campaign and introduction to the special collection. Geophysical Research Letters, 45. https://doi.org/10.1029/2018GL079032

Lasue, J., Cousin, A., Meslin, P.-Y., Mangold, N., Wiens, R. C., Berger, G., et al. (2018). Martian eolian dust probed by ChemCam. Geophysical Research Letters. https://doi.org/10.1029.2018GL079210

Leshin, L. A., Mahaffy, P. R., Webster, C. R., Cabane, M., Coll, P., Conrad, P. G., et al. (2013). Volatile, isotope, and organic analysis of Martian fines with the Mars curiosity rover. Science, $341(6153), 1238937$. https://doi.org/10.1126/science.1238937

Lybrand, R. A., Bockheim, J. G., Ge, W., Graham, R. C., Hlohowskyj, S. R., Michalski, G., et al. (2016). Nitrate, perchlorate, and iodate co-occur in coastal and inland deserts on Earth. Chemical Geology, 442, 174-186. https://doi.org/10.1016/j.chemgeo.2016.05.023

Mahaffy, P. R., Webster, C., Cabane, M., Conrad, P., Coll, P., Atreya, S., et al. (2012). The sample analysis at Mars investigation and instrument suite. Space Science Reviews, 170(1-4), 401-478. https://doi.org/10.1007/s11214-012-9879-z

Malespin, C. A., Freissinet, C., Glavin, D. P., Mahaffy, P. R., Millan, M., Buch, A., et al. (2018). The first complete SAM wet chemistry experiment on Mars, in 49th Lunar and Planetary Science Conference, edited, p. 2083, Lunar and Planetary Institute, Houston.

Mancinelli, R. L. (1996). The search for nitrogen compounds on the surface of Mars. Advances in Space Research, 18(12), 241-248. https://doi. org/10.1016/0273-1177(96)00113-5

McAdam, A., Eigenbrode, J., Young, K., Bleacher, J., Knudson, C., Rogers, D., et al. (2015). MSL SAM-like analyses of Hawaiian Altered Basaltic Materials: Implications for Analyses by the Mars Science Laboratory, in AGU Fall Meeting Abstracts, Edited.

McAdam, A., Sutter, B., Franz, H., Hogancamp, J., Knudson, C., Andrejkovičová, S., et al. (2017). Constraints on the mineralogy of Gale Crater mudstones from MSL SAM evolved water, edited, p. 1853

McAdam, A. C., Franz, H. B., Sutter, B., Archer, P. D., Freissinet, C., Eigenbrode, J. L., et al. (2014). Sulfur-bearing phases detected by evolved gas analysis of the Rocknest aeolian deposit, Gale Crater, Mars. Journal of Geophysical Research: Planets, 119, 373-393. https://doi.org/10.1002/2013JE004518

Ming, D., Archer, P., Glavin, D., Eigenbrode, J., Franz, H., Sutter, B., et al. (2014). Volatile and organic compositions of sedimentary rocks in Yellowknife Bay, Gale crater, Mars. Science, 343(6169), 1245267. https://doi.org/10.1126/science.1245267

Minitti, M., Kah, L., Yingst, R., Edgett, K., Anderson, R., Beegle, L., et al. (2013). MAHLI at the Rocknest sand shadow: Science and science enabling activities. Journal of Geophysical Research: Planets, 118, 2338-2360. https://doi.org/10.1002/2013JE004426

Morris, R. V., Ruff, S. W., Gellert, R., Ming, D. W., Arvidson, R. E., Clark, B. C., et al. (2010). Identification of carbonate-rich outcrops on Mars by the Spirit rover. Science, 329(5990), 421-424. https://doi.org/10.1126/science.1189667

Mu, J., \& Perlmutter, D. (1982). Thermal decomposition of metal nitrates and their hydrates. Thermochimica Acta, 56(3), 253-260. https://doi. org/10.1016/0040-6031(82)87033-0

Nachon, M., Mangold, N., Forni, O., Kah, L. C., Cousin, A., Wiens, R. C., et al. (2017). Chemistry of diagenetic features analyzed by ChemCam at Pahrump Hills, Gale crater, Mars. Icarus, 281, 121-136. https://doi.org/10.1016/j.icarus.2016.08.026

Navarro-González, R., Coll, P., Sutter, B., Stern, J., Mckay, C., Martín-Torres, F., et al. (2018). Detection of nitrites by the Sample Analysis at Mars (SAM) instrument. Implications for the oxidation state of the atmosphere, in Lunar and Planetary Science Conference, edited, p. 1754.

O'Connell-Cooper, C. D., Spray, J. G., Thompson, L. M., Gellert, R., Berger, J. A., Boyd, N. I., et al. (2017). APXS derived chemistry of the Bagnold dune sands: Comparisons with Gale crater soils and the global Martian average. Journal of Geophysical Research: Planets, 122, 2623-2643. https://doi.org/10.1002/2017JE005268

Rampe, E. B., Lapotre, M., Bristow, T. F., Arvidson, R. E., Morris, R. V., Achilles, C. N., et al. (2018). Sand mineralogy within the Bagnold Dunes, Gale crater, as observed in situ and from orbit. Geophysical Research Letters, 45. https://doi.org/10.1029/2018GL079073

Rogers, A. D., \& Bandfield, J. L. (2009). Mineralogical characterization of Mars Science Laboratory candidate landing sites from THEMIS and TES data. Icarus, 203(2), 437-453. https://doi.org/10.1016/j.icarus.2009.04.020

Schmidt, M. E., Campbell, J. L., Gellert, R., Perrett, G. M., Treiman, A. H., Blaney, D. L., et al. (2014). Geochemical diversity in first rocks examined by the Curiosity Rover in Gale crater: Evidence for and significance of an alkali and volatile rich igneous source. Journal of Geophysical Research: Planets, 119, 64-81. https://doi.org/10.1002/2013JE004481

Sephton, M. (2012). Pyrolysis and mass spectrometry studies of meteoritic organic matter. Mass Spectrometry Reviews, 31(5), 560-569. https://doi.org/10.1002/mas.20354

Smith, M. L., Claire, M. W., Catling, D. C., \& Zahnle, K. J. (2014). The formation of sulfate, nitrate and perchlorate salts in the Martian atmosphere. Icarus, 231, 51-64. https://doi.org/10.1016/j.icarus.2013.11.031

Stern, J. C., Sutter, B., Freissinet, C., Navarro-Gonzalez, R., McKay, C. P., Archer, P. D., et al. (2015). Evidence for indigenous nitrogen in sedimentary and aeolian deposits from the Curiosity rover investigations at Gale crater, Mars. Proceedings of the National Academy of Sciences of the United States of America, 112(14), 4245-4250. https://doi.org/10.1073/pnas.1420932112

Stern, J. C., Sutter, B., Jackson, W. A., Navarro-González, R., McKay, C. P., Ming, D. W., et al. (2017). The nitrate/(per) chlorate relationship on Mars. Geophysical Research Letters, 44, 2643-2651. https://doi.org/10.1002/2016GL072199

Sullivan, R., Arvidson, R., Bell, J. F., Gellert, R., Golombek, M., Greeley, R., et al. (2008). Wind-driven particle mobility on Mars: Insights from Mars Exploration Rover observations at El Dorado and surroundings at Gusev Crater. Journal of Geophysical Research, 113, E06S07. https://doi.org/10.1029/2008JE003101

Sullivan, R., \& Kok, J. F. (2017). Aeolian saltation on Mars at low wind speeds. Journal of Geophysical Research: Planets, 122, 2111-2143. https://doi.org/10.1002/2017JE005275

Sutter, B., Boynton, W. V., Ming, D. W., Niles, P. B., Morris, R. V., Golden, D. C., et al. (2012). The detection of carbonate in the martian soil at the Phoenix landing site: A laboratory investigation and comparison with the thermal and evolved gas analyzer (TEGA) data. Icarus, 218(1), 290-296. https://doi.org/10.1016/j.icarus.2011.12.002

Sutter, B., McAdam, A. C., Mahaffy, P. R., Ming, D. W., Edgett, K. S., Rampe, E. B., et al. (2017). Evolved gas analyses of sedimentary rocks and eolian sediment in Gale Crater, Mars: Results of the Curiosity Rover's Sample Analysis at Mars (SAM) instrument from Yellowknife Bay to the Namib Dune. Journal of Geophysical Research: Planets, 122, 2574-2609. https://doi.org/10.1002/2016JE005225

Treiman, A. H., Bish, D. L., Vaniman, D. T., Chipera, S. J., Blake, D. F., Ming, D. W., et al. (2016). Mineralogy, provenance, and diagenesis of a potassic basaltic sandstone on Mars: CheMin X-ray diffraction of the Windjana sample (Kimberley area, Gale crater). Journal of Geophysical Research: Planets, 121, 75-106. https://doi.org/10.1002/2015JE004932

Vaniman, D., Bish, D., Ming, D., Bristow, T., Morris, R., Blake, D., et al. (2014). Mineralogy of a mudstone at Yellowknife Bay, Gale crater, Mars. Science, 343(6169), 1243480. https://doi.org/10.1126/science.1243480

Weitz, C. M., Sullivan, R. J., Lapotre, M. G. A., Rowland, S. K., Grant, J. A., Baker, M., \& Yingst, R. A. (2018). Sand grain sizes and shapes in Aeolian Bedforms at Gale Crater, Mars. Geophysical Research Letters, 45. https://doi.org/10.1029/2018GL078972

Wilson, E. H., Atreya, S. K., Kaiser, R. I., \& Mahaffy, P. R. (2016). Perchlorate formation on Mars through surface radiolysis initiated atmospheric chemistry: A potential mechanism. Journal of Geophysical Research: Planets, 121, 1472-1487. https://doi.org/10.1002/2016JE005078 